\title{
Genomic insights into the overlap between psychiatric disorders: implications for research and clinical practice
}

\author{
Joanne L Doherty and Michael J Owen*
}

\begin{abstract}
Psychiatric disorders such as schizophrenia, bipolar disorder, major depressive disorder, attention-deficit/hyperactivity disorder and autism spectrum disorder are common and result in significant morbidity and mortality. Although currently classified into distinct disorder categories, they show clinical overlap and familial co-aggregation, and share genetic risk factors. Recent advances in psychiatric genomics have provided insight into the potential mechanisms underlying the overlap between these disorders, implicating genes involved in neurodevelopment, synaptic plasticity, learning and memory. Furthermore, evidence from copy number variant, exome sequencing and genome-wide association studies supports a gradient of neurodevelopmental psychopathology indexed by mutational load or mutational severity, and cognitive impairment. These findings have important implications for psychiatric research, highlighting the need for new approaches to stratifying patients for research. They also point the way for work aiming to advance our understanding of the pathways from genotype to clinical phenotype, which will be required in order to inform new classification systems and to develop novel therapeutic strategies.
\end{abstract}

\section{The overlap between psychiatric disorders: challenges to current nosology}

Psychiatric disorders are common in the population [1] and result in considerable morbidity and mortality [2]. Over the decades, psychiatric classification systems such as the Diagnostic and Statistical Manual of Mental Disorders (DSM) [3] and the International Classification of Diseases (ICD) [4] have been developed and revised in order to

\footnotetext{
* Correspondence: owenmj@cardiff.ac.uk

The MRC Centre for Neuropsychiatric Genetics and Genomics and The

Neuroscience and Mental Health Research Institute, Cardiff University, Hadyn Ellis Buildin, Maindy Road, Cardiff CF24 4HQ, UK
}

improve the reliability of clinical diagnosis, inform treatment strategies and guide research. However, in the absence of objective diagnostic tests for psychiatric disorders, such classifications are largely descriptive and syndromic, describing constellations of symptoms and signs that tend to occur together. These classification systems thus define psychiatric disorders such as schizophrenia, bipolar disorder, major depressive disorder, attention-deficit/hyperactivity disorder (ADHD) and autism spectrum disorder (ASD) categorically, according to the quality and quantity of symptoms and signs present. Treatment guidelines have been developed on the basis of these diagnostic categories. For example, schizophrenia is treated with antipsychotics, bipolar disorder with mood stabilizers and antipsychotics, major depression with antidepressants and ADHD with psychostimulants (Table 1).

However, it is widely acknowledged that there is substantial heterogeneity within diagnostic categories and that the boundary between disorder and 'normality' is not always clear. Furthermore, many symptoms and signs overlap between disorder categories and patients often present with features of more than one disorder. In some cases, this overlap has been dealt with by recognizing diagnostic 'interforms' such as schizoaffective disorder [11], or by recognizing 'comorbidity', whereby patients are diagnosed with more than one disorder. Comorbidity is often obscured in research by the use of diagnostic hierarchies or exclusions. For example, until the publication of the most recent edition of the DSM (DSM-5), it was not possible to co-diagnose ASD and ADHD. However, it is estimated that 30 to $80 \%$ of children with ASD also have ADHD [12,13]. Given these diagnostic issues, it is perhaps unsurprising that neuroscientific advances have thus far failed to identify specific risk factors or biomarkers that map onto disorder categories on a oneto-one basis. Indeed, there is accumulating evidence supporting biological overlap between disorders, fuelling investigation into the underlying mechanisms. 


\begin{tabular}{|c|c|c|c|c|c|}
\hline Disorder & Core features & Associated features & $\begin{array}{l}\text { Typical age of } \\
\text { onset (years) }\end{array}$ & $\begin{array}{l}\text { Lifetime } \\
\text { prevalence } \\
\text { (\%) }\end{array}$ & $\begin{array}{l}\text { Pharmacological } \\
\text { management }\end{array}$ \\
\hline ADHD & $\begin{array}{l}\text { Inattention } \\
\text { Hyperactivity } \\
\text { Impulsivity }\end{array}$ & Cognitive impairment & 7 to 12 & $5[5]$ & $\begin{array}{l}\text { Psychostimulants } \\
\text { (for example, methylphenidate) }\end{array}$ \\
\hline ASD & $\begin{array}{l}\text { Deficits in social communication } \\
\text { and social interaction } \\
\text { Restricted and repetitive behaviors }\end{array}$ & $\begin{array}{l}\text { Cognitive impairment } \\
\text { Hallucinations } \\
\text { Delusions }\end{array}$ & $<3$ & 1 to 2 [6-8] & $\begin{array}{l}\text { No recommended drug } \\
\text { treatment } \\
\text { Medication used to treat } \\
\text { comorbidities if present }\end{array}$ \\
\hline Schizophrenia & $\begin{array}{l}\text { Hallucinations } \\
\text { Delusions } \\
\text { Disorganized speech or } \\
\text { behavior Apathy } \\
\text { Lack of emotional reactivity }\end{array}$ & $\begin{array}{l}\text { Cognitive impairment } \\
\text { Discrete episodes of elevated, } \\
\text { irritable or agitated mood } \\
\text { Episodes of low mood }\end{array}$ & 16 to 30 & $0.7[9]$ & $\begin{array}{l}\text { Antipsychotics } \\
\text { (for example, risperidone) }\end{array}$ \\
\hline $\begin{array}{l}\text { Bipolar } \\
\text { disorder }\end{array}$ & $\begin{array}{l}\text { Discrete episodes of elevated, } \\
\text { irritable or agitated mood }\end{array}$ & $\begin{array}{l}\text { Episodes of low mood } \\
\text { Hallucinations } \\
\text { Delusions }\end{array}$ & 18 to 40 & $1[10]$ & $\begin{array}{l}\text { Mood stabilizers (for example, } \\
\text { lithium)Antipsychotics } \\
\text { (for example, olanzapine) }\end{array}$ \\
\hline $\begin{array}{l}\text { Major } \\
\text { depressive } \\
\text { disorder }\end{array}$ & $\begin{array}{l}\text { Low mood } \\
\text { Loss of interest or pleasure } \\
\text { Lack of energy }\end{array}$ & Psychosis & 20 to 45 & $12.5[10]$ & $\begin{array}{l}\text { Antidepressants } \\
\text { (for example, citalopram) }\end{array}$ \\
\hline
\end{tabular}

$A D H D$, attention-deficit/hyperactivity disorder; $A S D$, autism spectrum disorder.

Advances in genomic technology have been key to this paradigm shift in psychiatric research. These studies provide converging evidence across a number of different levels, supporting the hypothesis that genetic risk factors are shared between disorders and challenging the validity of the classification systems currently used in research and clinical practice. The evidence suggests that investigating pathways common across disorders may help us to understand the etiology of psychiatric illness. This could revolutionize our approach to the diagnosis and treatment of these complex disorders. Here, we review recent evidence from family and genomic studies, which support an overlapping and complex genetic architecture for psychiatric disorders and provide new avenues for further investigation of underlying mechanisms.

\section{Family studies}

Twin, family and adoption studies have provided heritability estimates for the major psychiatric disorders, highlighting an important role for genetic factors in the etiology of mental disorders [11,14-18].

In the late 19th century, Emil Kraepelin, a prominent German psychiatrist, distinguished between 'dementia praecox' (later termed schizophrenia) and manicdepressive psychosis (later termed bipolar disorder) as the two most common functional psychoses. Many family studies seemed to support this so-called 'Kraepelinian dichotomy', finding no familial relationship between schizophrenia and bipolar disorder, suggesting that these disorders 'breed true' [19-22]. These studies typically used hierarchical main-lifetime diagnoses - the predominant diagnosis an individual is given - in which schizophrenia was ranked higher than bipolar disorder. Therefore, patients who had several manic or depressive episodes in the past but who mostly had symptoms of schizophrenia later in the course of their illness would be given a main-lifetime diagnosis of schizophrenia. However, when non-hierarchical approaches were used, familial co-aggregation between schizophrenia, bipolar disorder [23] and schizoaffective disorder [24] was observed. This overlap in familial risk was confirmed in a meta-analysis of family studies of schizophrenia and bipolar disorder [25]. Recent large-scale population studies in Swedish cohorts have expanded on this, showing that a family history of schizophrenia, mood disorders, ASD and ADHD is associated with cross-disorder risk [26,27]. The overlap between major depressive disorder and other mental disorders is less clear. A meta-analysis of family high-risk studies recently compared offspring of parents with schizophrenia, bipolar disorder and major depressive disorder [28]. The study showed that offspring of adults with schizophrenia, bipolar disorder or major depressive disorder had a $32 \%$ probability of developing one of these disorders themselves by adulthood and that risks to offspring were not limited to their parent's index disorder. For example, offspring of patients with schizophrenia or bipolar disorder had an increased risk of schizophrenia, bipolar disorder and major depressive disorder. However, although the relative risk of schizophrenia and bipolar disorder was also elevated in offspring of parents with depression, this finding did not reach statistical significance.

Vandeleur and colleagues [29] recently studied families with mood disorders (schizoaffective disorder, bipolar 
disorder and major depressive disorder), taking both categorical (disorder-based) and dimensional (symptombased) approaches. Interestingly, the authors found that psychotic, manic and depressive symptoms were transmitted independently, suggesting that studying familial transmission of symptom dimensions may help to dissect clinical phenotypes in order to better understand the differential effects of genetic and environmental risk factors.

It has long been known that schizophrenia is associated with cognitive impairment and that this often predates the onset of psychotic symptoms [30]. Family studies show that the offspring of parents with schizophrenia have worse cognitive function than the offspring of unaffected parents [31], and that cognitive impairment is associated with familial risk of schizophrenia [32]. Applying genetic modeling to a combined family and twin sample, Toulopoulou and colleagues [33] showed that a large proportion of the phenotypic correlations between schizophrenia and cognition are due to shared genetic effects.

Taken together, the evidence from family studies suggests that psychiatric disorders may be co-inherited but also suggests that independent genetic and environmental risk factors are likely to be important in determining the ultimate clinical phenotype.

\section{Genomic studies}

The epidemiological studies discussed above used the genetic relationships between individuals to study the co-inheritance of psychiatric disorders. Advances in genomic technology, including array-based genome-wide association studies (GWAS), and exome-sequencing techniques, have allowed the potential genetic mechanisms underlying the overlap between psychiatric disorders to be investigated more directly. Like other complex diseases such as hypertension and diabetes, psychiatric disorders are not inherited in a Mendelian fashion but have a complex genetic architecture involving a spectrum of mutations from small DNA sequence variations to large chromosomal rearrangements. Not only do these mutations vary in their size, they also vary in their frequency and associated effect sizes. Below, we discuss recent evidence for overlap in genetic risk factors from GWAS of single nucleotide polymorphisms (SNPs), studies of copy number variants (CNVs) and exomesequencing studies of single nucleotide variants (SNVs), insertions and deletions (indels).

\section{Single nucleotide polymorphisms}

The introduction of genome-wide association platforms has enabled researchers to study large samples of patients and controls to identify common variants (minor allele frequency $>0.01$ ) with cross-disorder associations.
The markers used in these studies are SNPs: points in the DNA sequence where the nucleotide base varies in the population. In a recent paper published by the Cross-Disorder Group of the Psychiatric Genomics Consortium (PGC), four SNPs were identified as being significantly associated with the five psychiatric disorders studied: schizophrenia, bipolar disorder, major depressive disorder, ASD and ADHD [34]. Two of the SNPs were located in genes encoding L-type voltage-gated calcium channel subunits (CACNA1C and CACNB2). CAC$N A 1 C$ has previously been reported as having genomewide significant associations with schizophrenia, bipolar disorder and major depressive disorder [35-38], and therefore there is strong evidence implicating calcium channel signaling in the pathophysiology of mental disorders. Other loci with cross-disorder associations include ANK3 [36,37], ZNF804A [39,40] and NCAN $[41,42]$, all of which have been reported in GWAS of schizophrenia and bipolar disorder.

To date, GWAS of common SNPs have shown that individual SNPs have modest effect sizes (typical odds ratio $<1.2$ ). It is therefore hypothesized that many common SNPs act together to influence risk of psychiatric disorders. Schizophrenia GWAS data support a polygenic basis for the disorder and estimate that common SNPs explain approximately one-third of the total variation in liability to schizophrenia $[43,44]$. These data also show that genetic liability is substantially shared with bipolar disorder [43]. Polygenic score analysis of common variants has provided further evidence for shared genetic risk across disorders. This approach uses a set of the top risk-associated alleles from a case-control 'discovery' GWAS sample to generate an aggregate score that can be used to test for differences between cases and controls in an independent 'target' sample. Scores are assigned to each individual based on the number of risk alleles they carry, weighted by the effect size for each variant. These scores are weighted by the effect size for each variant. Using this approach, it has been shown that alleles that are overrepresented in schizophrenia cases are also overrepresented in cases of bipolar disorder [43] and ADHD [45]. However, schizophrenia alleles were not found to be overrepresented in an ASD cohort [46]. Aggregate polygenic risk scores in the PGC sample also showed cross-disorder effects, which were strongest for adult-onset disorders [34]. Furthermore, polygenic risk scores have been used to investigate the association between schizophrenia and cognitive impairment. The Cognitive Genomics Consortium reported that schizophrenia polygenic risk scores were correlated with cognitive ability: higher 'schizophrenia load' being associated with lower cognitive ability. The authors also calculated cognitive polygenic scores and found that patients with schizophrenia had more alleles associated with poor cognitive performance and fewer alleles 
associated with good cognitive performance than controls [47]. In another study, schizophrenia polygenic risk score was associated with lower cognitive ability at age 70 years and with greater cognitive decline between childhood and old age [48]. However, another recent study failed to find an association between polygenic risk for schizophrenia and IQ variation in either schizophrenia cases or controls [49].

An alternative method for investigating the SNP-based genetic overlap between disorders is to use a method known as genome complex trait analysis (GCTA) [50] to calculate SNP-based genetic correlations. This method estimates the variance explained by all SNPs for a complex trait rather than testing the association of any particular SNP to the trait. It assumes an additive model and therefore does not account for gene-gene interactions. Using this method, it has been estimated that common variants contribute between 17 and $29 \%$ to the variation in liability to mental disorders [51]. High correlation was found between schizophrenia and bipolar disorder; moderate correlation between major depressive disorder and schizophrenia, major depressive disorder and bipolar disorder, and major depressive disorder and ADHD; and a small but significant correlation between schizophrenia and ASD. Interestingly, no correlations were found between other pairs of disorders, including ASD and ADHD, bipolar disorder and ADHD, or schizophrenia and ADHD. This was unexpected given the considerable phenotypic overlap between these disorders and data from family, twin and linkage studies, which suggest shared genetic risk factors [27,52-55]. However, when compared with adult-onset disorders, ADHD and ASD cohort sizes were relatively small in this study and therefore it may have been underpowered to detect SNP-based correlations between these disorders. Furthermore, there is increasing evidence for the role of rare genetic variants such as CNVs in neurodevelopmental disorders and it is possible that these play a more significant role in the overlap of ADHD and ASD than common SNPs, although further studies of larger samples will be needed in order to adequately address this.

\section{Copy number variants}

Despite the high heritability of mental disorders reported in family studies, GWAS findings to date suggest that common variants only explain a relatively small proportion (about a third) of the genetic variation in liability to psychiatric illness [56]. Furthermore, the lack of SNPbased genetic correlation between disorders such as ADHD and ASD suggests a role for other types of variant in the genetic architecture of mental disorders. There is increasing evidence that rare structural variants (those present in $<1 \%$ of the population), such as CNVs, may also be important. Owing to their low frequency in the population, these variants are unlikely to be tagged by common SNPs and therefore bring independent information about the genetic etiology of psychiatric disorders.

Several studies have clearly demonstrated enrichment for rare CNVs in psychiatric and developmental disorders. For example, it has been shown that CNV burden is higher in patients with schizophrenia [57-59], ADHD [60,61], ASD [62], intellectual disability (ID) and developmental delay [63] than in healthy controls. Furthermore, $\mathrm{CNV}$ load and the ratio of de novo to inherited CNVs correlate with the severity of developmental disability [63].

The role of CNVs in mood disorders is less clear. Several studies have shown that patients with bipolar disorder have a low burden of rare CNVs [64-66]. However, singleton deletions and de novo CNVs have been found to occur at a higher rate in bipolar disorder cases than in controls, particularly in early onset cases $[67,68]$. The only genome-wide study of CNVs in major depressive disorder found that deletions $>100$ kilobases $(\mathrm{kb})$ in size were significantly enriched in patients with recurrent depression but that such CNVs explained only $0.87 \%$ of the variance between cases and controls [69].

Microdeletions and duplications conferring risk of schizophrenia have been reported at a number of chromosomal locations (Table 2) affecting genes involved in numerous processes such as synaptic signaling, neuronal migration, neurotransmitter metabolism and myelination. These CNVs show incomplete penetrance and have pleiotropic effects, resulting in variable clinical phenotypes. ID, ASD, ADHD, and mood and anxiety disorders commonly occur, as do epilepsy, congenital malformations, facial dysmorphology and developmental delay. Furthermore, 'control' carriers of CNVs (that is, those without a diagnosis of a psychotic illness, ASD, ID or developmental delay) at a number of known schizophrenia risk loci, including chromosomes 15q11.2 and 16p11.2, have been shown to have cognitive impairment, the severity of which is intermediate between that observed in patients with schizophrenia and population controls [70].

Recent evidence suggests that CNVs may not only increase risk of psychiatric disorders, they may also exert protective effects. The 22q11.2 deletion is the strongest known genetic risk factor for schizophrenia. Recently, Rees and co-workers [110] found that the reciprocal duplication is less common in patients with schizophrenia than in controls. This implies that studying CNVs may also help us to understand mechanisms underlying resilience to mental disorders.

\section{Single nucleotide variants and indels}

GWAS and array-based techniques have enabled the detection of small common $(>1 \%)$ and large rare $(<1 \%) \mathrm{mu}-$ tations. The development of exome-sequencing platforms has enabled the identification of small rare coding 
Table 2 Copy number variants associated with schizophrenia, their penetrance for schizophrenia, and associations with other psychiatric disorders and intellectual disability

\begin{tabular}{lllll}
\hline Locus & Copy number change & Penetrance & Associations & References \\
\hline $1 q 21.1$ & Deletion/duplication & $5.2 / 2.9$ & ID, ASD, ADHD & {$[57,58,71-75]$} \\
2 p16.3 (NRXN1) & Deletion & 6.4 & ID, ASD & {$[57,58,74,76-81]$} \\
$3 q 29$ & Deletion & 18.0 & ID, ASD & {$[73-75,82]$} \\
$7 q 11.2$ & Duplication & 6.0 & ID, ASD, ADHD, anxiety disorders & {$[73,74,83-86]$} \\
$15 q 11.2$ & Deletion & 2.0 & ID, ASD, ADHD, OCD & {$[72-74,81,87-89]$} \\
$15 q 11-13$ & Duplication & 4.2 & ID, ASD & {$[73,74,90-92]$} \\
$15 q 13.3$ & Deletion & 4.7 & ID, ASD, ADHD & {$[57,72-75,93-96]$} \\
$16 p 11.2$ & Deletion/duplication & $2.6 / 8.0$ & ID, ASD, ADHD, mood disorders, anxiety disorders & {$[62,73,74,91,97-102]$} \\
$16 p 13.11$ & Duplication & 2.2 & ID, ASD, ADHD & {$[61,73,74,81,103,104]$} \\
$17 q 12$ & Deletion & 4.0 & ID, ASD & {$[73,74,105]$} \\
$22 q 11.2$ & Deletion & 12 & ID, ASD, ADHD, mood disorders, anxiety disorders & {$[57,73,74,106-109]$} \\
\hline
\end{tabular}

$A S D$, autism spectrum disorder; ADHD, attention-deficit/hyperactivity disorder; ID, intellectual disability; OCD, obsessive-compulsive disorder.

mutations, which could not previously be detected using GWAS or array-based techniques. Using samples of trios (both parents and one child) and quads (both parents with two children), de novo gene-disrupting SNVs and indels have been found to occur at higher rates in probands with ASD [111-114] and ID [115,116], being present in up to $14 \%$ of ASD cases $[113,114]$ and up to $55 \%$ of ID cases [115] in the sampled cohorts. Furthermore, mutation rates were found to correlate with increasing paternal [111-113] and maternal $[111,112]$ age, which is in line with epidemiological evidence for the positive correlation between parental age and rates of disorders in offspring [117-120].

The first exome-sequencing studies in schizophrenia found higher than expected rates of non-synonymous de novo mutations in small samples of patients $[121,122]$. Two recent and much larger studies [123,124] did not observe an increased rate of either non-synonymous or loss of function de novo or inherited mutations in schizophrenia. However, enrichment of loss of function de novo mutations did occur in schizophrenia cases likely to have the greatest intellectual impairment (lowest scholastic attainment), although these did not include cases with diagnoses of severe intellectual impairment. Moreover, genes with de novo mutations in schizophrenia overlapped with those affected by de novo mutations in ASD and ID but not in controls, with loss of function mutations enriched even in the very small subset of genes $(N=7)$ with recurrent loss of function de novo mutations in ASD or ID [123]. These findings therefore demonstrate shared genetic overlap between schizophrenia, ASD and ID at the resolution not just of loci or even of individual genes, but also at the level of mutations with similar functional (loss of function) impacts. The authors also observed that the genes hit by de novo mutations and the mutation sites themselves showed the highest degree of evolutionary conservation (a proxy measure of functional importance) in ID, then in ASD, with least conservation seen in schizophrenia. These findings suggest that highly disruptive mutations play a relatively small role in schizophrenia, and also that the disorders differ by severity of functional impairment.

\section{Potential biological mechanisms for shared genetic risk}

Recently, evidence for the convergence of genetic findings onto a coherent set of biological processes in psychiatric disorders has been accumulating. Results from GWAS [34,44], CNV [83,125] and sequencing studies $[114,123,124]$ point to highly functionally related sets of post-synaptic proteins involved in neurodevelopmental processes, synaptic plasticity, learning and memory. These include L-type calcium channels, post-synaptic scaffolding proteins involved in NMDA ( $N$-methyl-D-aspartate) signal transduction, proteins that interact with ARC (activity-regulated cytoskeleton-associated protein), referred to as the ARC complex [83], and brainexpressed genes that are repressed by fragile $\mathrm{X}$ mental retardation protein (FMRP) [123,126].

These findings are notable for their consistency across several studies using different designs, and for their convergence onto a set of biological processes involved in the regulation of synaptic plasticity, particularly at glutamatergic synapses. Although there appears to be a concentration on post-synaptic mechanisms, some implicated genes, including the L-type calcium channels and neurexin 1 (an associated CNV locus [127]) also exert effects on plasticity pre-synaptically. Furthermore, these synaptic genes have been implicated in cognition [128] as well as in a range of psychiatric disorders, including schizophrenia, bipolar disorder, ASD and ID. However, the degree to which the associated pathways cross current diagnostic boundaries remains to be fully established. It is highly unlikely that 
this will represent the only set of biological processes implicated in these disorders, but the identification of at least one system involved in risk for schizophrenia and related disorders paves the way for more detailed mechanistic studies and potentially for stratified and novel therapeutic approaches.

Convergent support for glutamatergic synaptic processes is encouraging, but as already mentioned, it is likely that other processes are involved. There is a highly convincing body of evidence implicating dopaminergic dysfunction in the genesis of psychotic symptoms, which occur commonly in schizophrenia and bipolar disorder but that also occur in other neurodevelopmental disorders [129]. Indeed, the mechanism of action of antipsychotic drugs is understood to largely depend upon the blockade of dopamine D2 receptors. Understanding the relationship between glutamatergic dysfunction, which is closely related to cognitive impairment, and dopamine abnormalities is likely to be a fruitful approach to understanding how psychosis arises in schizophrenia and related disorders.

It seems probable that genetic disruption of the synaptic processes implicated to date will have widespread impacts on brain function and impair information processing within local, regional and even whole-brain networks - for example, by affecting excitatory-inhibitory balance and/or synaptic plasticity. Therefore, it is not surprising that mutations in genes involved in these processes affect cognitive function irrespective of the presence of comorbid psychopathology $[48,70]$.

A spectrum of neurodevelopmental causality has previously been proposed to underlie the overlap between psychiatric disorders [130,131]. This proposed model suggests that psychiatric disorders and ID lie on a gradient of severity, with ID at one extreme and mood disorders at the other. Recent genomic evidence supports such a model and extends it to include a gradient of mutational severity or mutational load as well as cognitive impairment (Figure 1). Under such a model, genetic factors (such as the nature, quantity, size and location of deleterious genetic variants) and environmental factors leading to early brain insult act together to alter neurodevelopmental trajectories: the timing, severity, anatomical location and extent of the deviation from 'normality' determining the ultimate clinical phenotype. Further investigation, integrating genetic findings with cellular, animal, clinical and neuroimaging research, will shed more light on whether such a model is plausible.

\section{Implications for clinical diagnosis, management and research}

Advances in our understanding of the genetic architecture of psychiatric disorders support the long-standing clinical observation of overlap in the symptoms and signs of these disorders, as well as the non-specificity of many environmental risk factors [131]. However, we are still some way off having sufficient new insights from genetics and neuroscience to replace current diagnostic approaches in the clinic. It is too early to say how advances in neuroscience and genetics will affect classification and diagnosis. Although current diagnostic categories are likely to remain clinically useful where they can best inform management and prognosis, these categories will require modification as further research indicates closer relationships of specific phenotypes and endophenotypes to mechanisms, and will probably need to include both dimensional (symptom-based) and categorical (syndrome-based) components.

What is clear, however, is that research into etiology and pathogenesis does require a radical overhaul in how we diagnose psychiatric illness, moving from categorical, hierarchical diagnoses based on consensus opinion towards a more dimensional approach informed by advances in our understanding of brain mechanisms. Indeed, such an effort is currently underway by the Research Domain Criteria (RDoC) project $[132,133]$. This project aims to provide the data required to build a new classification system based on underlying biology. While such a step is clearly needed, it will take a decade or more for enough evidence to be accumulated to develop a system that is suitable for clinical practice. However, an immediate implication of recent genetic findings and the $\mathrm{RDoC}$ project is the need to study patients who fall into the 'gray area' between disorder categories [134] or who have 'subthreshold' symptoms.

Pediatricians and clinical geneticists are increasingly using genetic testing for patients referred with congenital malformations, facial dysmorphology, developmental delay, ID and ASD $[135,136]$. So far, genetic testing has not been widely adopted in psychiatry (see [137] for an overview of some of the ethical issues involved in genetic testing in psychiatry). However, many CNVs associated with developmental abnormalities (for example, the 22q11.2 deletion) increase risk of mental health problems across the lifespan. A recent study by van den Bree and colleagues [138] found that the internet was the main source of parents' information about psychiatric problems associated with 22q11.2 deletion syndrome, while another study reported that almost half of genetic counselors were uncomfortable discussing psychiatric disorders with affected families [139]. This suggests that there should be greater liaison between pediatricians, clinical geneticists and psychiatrists in order to appropriately counsel families about these risks and monitor symptoms.

There is now clear evidence that childhood-onset disorders often persist into adulthood [140,141] and that many adult-onset disorders have their roots in childhood 


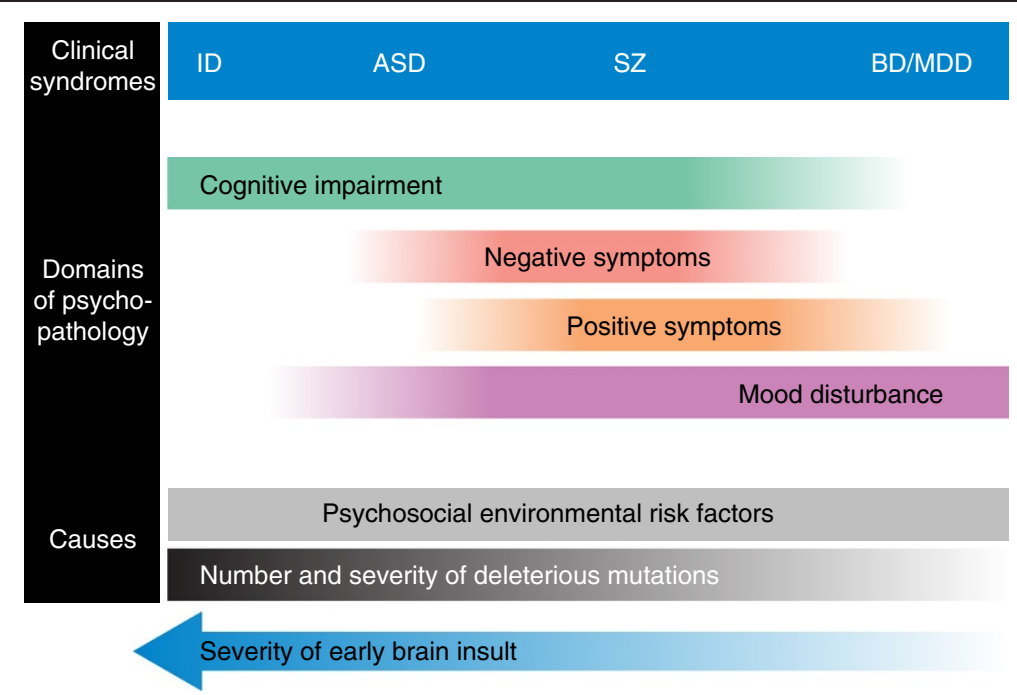

Figure 1 Simplified representation of the hypothesized relationship between the number and severity of deleterious genetic mutations and clinical syndromes. Psychiatric disorders as currently classified are shown as a neurodevelopmental continuum, with intellectual disability (ID) at one extreme and mood disorders at the other (see [130]). Domains of psychopathology overlap between the clinical syndromes, with the ultimate clinical phenotype being dependent on both genetic and environmental influences. Positive symptoms refer to abnormal thoughts, perceptions and behaviour, for example, hallucinations and delusions. Negative symptoms refer to disruption to normal emotions or behaviour, for example, apathy and lack of emotional reactivity. A gradient of mutational load and cognitive impairment is shown, with ID associated with the highest mutational load and most severe cognitive impairment, and mood disorders associated with the lowest mutational load/severity and least impaired cognitive function. The severity of individual syndromes is not represented. Owing to the lack of evidence from adequately powered genetic studies, attention-deficit/hyperactivity disorder (ADHD) has been omitted from the figure. ASD, autism spectrum disorder; BD, bipolar disorder; MDD, major depressive disorder; SZ, schizophrenia.

$[142,143]$. Also, it is well established that cognitive impairment is a core feature across several disorder categories [144-147]. Psychiatric secondary care services are, for the most part, segregated into those that manage children and adolescents, adults of working age, older adults and patients with intellectual disability, respectively. Furthermore, neurodevelopmental disorders are often managed by other services, including clinical genetics, pediatrics and neurology. The evidence from recent genomic studies suggests that the service settings in which patients with neurodevelopmental disorders find themselves depend to a large extent on when, and by whom, they happen to be diagnosed, and that a lifetime neurodevelopmental perspective should be adopted in the diagnosis and management of psychiatric disorders and ID. Effective communication between service providers is key to providing high-quality care, particularly during transitions from one service to another.

One of the major barriers to improving the outcome of patients with severe mental illness is the lack of effective pharmacological treatments that are well tolerated by patients. As a result, psychiatric disorders are associated with high rates of treatment resistance and non-compliance due to poor drug efficacy and unacceptable side effects. Despite considerable advances in neuroscience, there have been few if any notable advances in pharmacotherapy, and as a consequence of this and the perceived challenges of the field, many pharmaceutical companies are discontinuing research in neuroscience and psychiatry [148]. Recent genetic advances have identified risk alleles, candidate genes and molecular pathways that could be exploited in the effort to identify novel drug targets and psychotherapeutic agents. However, such developments are going to need substantial investment in order to translate genetic findings from the laboratory into clinical practice.

In this article, we have emphasized the accumulating evidence from genetic studies suggesting shared susceptibility across traditional diagnostic categories in psychiatry. This implies that at least some of the underlying biology may not be specific, or at least not at the level of current diagnoses. However, it is important to recognize that relatively non-specific risk factors that apply to a wide variety of cases are easier to identify than those associated with more specific outcomes. There is evidence from both family and genomic studies for risk alleles with differential effects on schizophrenia and bipolar disorder $[23,149]$ and also for alleles that have a degree of specificity to clinical phenotypes that do not necessarily relate well to traditional diagnostic categories [150]. Another example comes from the mounting evidence that large, rare CNVs that are more prevalent in schizophrenia are actually underrepresented in bipolar disorder $[64,65]$. Indeed, it seems highly probable that while 
psychiatric disorders, as currently defined, share risk genes and overlapping mechanisms, future research will identify risk alleles and mechanisms with more specific effects. The identification of risk alleles with greater phenotypic specificity will require researchers to tackle the problem of how to scale up detailed phenotyping to allow studies of the size required to detect genetic effects at robust levels of statistical significance. It also seems likely that we will have to move beyond crosssectional descriptions of psychopathology and assemble data on course and outcome as well as endophenotypes linked to underlying neurobiological mechanisms. Recent history in psychiatric genetics tells us that these efforts will have to be large scale and collaborative.

\section{Conclusions and future directions}

Clinical and epidemiological evidence for the overlap between psychiatric disorders has been available for some time. There is now increasing biological evidence for this overlap. Recent genetic findings suggest that psychiatric disorders have a complex genetic architecture and support the existence of a neurodevelopmental gradient of psychopathology and associated cognitive impairment. These findings highlight the need to improve current diagnostic systems and to develop better treatments targeted at underlying biology. Future research studying networks rather than individual genes and proteins, and relating network abnormalities to behavioral, neuroimaging and clinical phenotypes will be key to achieving these aims. However, the complexity of psychiatric phenotypes and the relative inaccessibility of the human brain pose considerable challenges to both basic and clinical neuroscientific research. It seems likely that there will need to be a focus on large-scale experiments, requiring interdisciplinary and international collaboration, if we are to make significant progress.

\footnotetext{
Abbreviations

ADHD: Attention-deficit/hyperactivity disorder; ASD: Autism spectrum disorder; CNV: Copy number variant; DSM: Diagnostic and statistical manual of mental disorders; GWAS: Genome-wide association studies; ICD: International classification of diseases; ID: Intellectual disability; indel: insertion and deletion; kb: kilobases; PGC: Psychiatric genomics consortium; RDoC: Research domain criteria; SNP: Single nucleotide polymorphism; SNV: Single nucleotide variant.
}

\section{Competing interests}

The authors declare that they have no competing interests.

\footnotetext{
Acknowledgements

MJO is supported by the Medical Research Council Centre (G0800509) and Program Grants (G0801418), the European Community's Seventh Framework Programme (HEALTH-F2-2010-241909 (Project EU-GEI)), the National Institute of Mental Health (2 P50MH066392-05A1) and a Wellcome Trust Strategic Award (100202/Z/12/Z). JLD is supported by a Wellcome Trust Clinical Research Training Fellowship (102003/Z/13/Z).
}

\section{References}

1. Kessler RC, Angermeyer M, Anthony JC, De Graaf R, Demyttenaere K, Gasquet I, De Girolamo G, Gluzman S, Gureje O, Haro JM, Kawakami N, Karam A, Levinson D, Medina Mora ME, Oakley Browne MA, Posada-Villa J, Stein DJ, Adley Tsang CH, Aguilar-Gaxiola S, Alonso J, Lee S, Heeringa S, Pennell BE, Berglund P, Gruber MJ, Petukhova M, Chatterji S, Ustün TB: Lifetime prevalence and age-of-onset distributions of mental disorders in the world health organization's world mental health survey initiative. World Psychiatry 2007, 6:168-176.

2. Whiteford HA, Degenhardt L, Rehm J, Baxter AJ, Ferrari AJ, Erskine HE, Charlson FJ, Norman RE, Flaxman AD, Johns N, Burstein R, Murray CJ, Vos T: Global burden of disease attributable to mental and substance use disorders: findings from the Global Burden of Disease Study 2010. Lancet 2013, 382:1575-1586.

3. American Psychiatric Association: Diagnostic and Statistical Manual of Mental Disorders. 5th edition. Arlington; 2013.

4. World Health Organisation: ICD-10 Classifications of Mental and Behavioural Disorder: Clinical Descriptions and Diagnostic Guidelines. Geneva; 1992.

5. Polanczyk G, de Lima MS, Horta BL, Biederman J, Rohde LA: The worldwide prevalence of ADHD: a systematic review and metaregression analysis. Am J Psychiatry 2007, 164:942-948.

6. Baron-Cohen S, Scott FJ, Allison C, Williams J, Bolton P, Matthews FE, Brayne C: Prevalence of autism-spectrum conditions: UK school-based population study. Br J Psychiatry 2009, 194:500-509.

7. Baird G, Simonoff E, Pickles A, Chandler S, Loucas T, Meldrum D, Charman T: Prevalence of disorders of the autism spectrum in a population cohort of children in South Thames: the Special Needs and Autism Project (SNAP). Lancet 2006, 368:210-215.

8. Blumberg SJ, Bramlett MD, Kogan MD, Schieve LA, Jones JR, Lu MC: Changes in Prevalence of Parent-Reported Autism Spectrum Disorder in School-Aged U.S. Children: 2007-2012. Number 65. National Center for Health Statistics; 2013.

9. Saha S, Chant D, Welham J, McGrath J: A systematic review of the prevalence of schizophrenia. PLoS Med 2005, 2:e141.

10. Merikangas KR, Jin R, He JP, Kessler RC, Lee S, Sampson NA, Viana MC, Andrade LH, Hu C, Karam EG, Ladea M, Medina-Mora ME, Ono Y, Posada-Villa J, Sagar R, Wells JE, Zarkov Z: Prevalence and correlates of bipolar spectrum disorder in the world mental health survey initiative. Arch Gen Psychiatry 2011, 68:241-251.

11. Cardno AG, Owen MJ: Genetic relationships between schizophrenia, bipolar disorder, and schizoaffective disorder. Schizophr Bull 2014. doi:10.1093/schbul/sbu016.

12. Simonoff E, Pickles A, Charman T, Chandler S, Loucas T, Baird G: Psychiatric disorders in children with autism spectrum disorders: prevalence, comorbidity, and associated factors in a population-derived sample. J Am Acad Child Adolesc Psychiatry 2008, 47:921-929.

13. Lee DO, Ousley OY: Attention-deficit hyperactivity disorder symptoms in a clinic sample of children and adolescents with pervasive developmental disorders. J Child Adolesc Psychopharmacol 2006, 16:737-746.

14. Taylor L, Faraone SV, Tsuang MT: Family, twin, and adoption studies of bipolar disease. Curr Psychiatry Rep 2002, 4:130-133.

15. Shih RA, Belmonte PL, Zandi PP: A review of the evidence from family, twin and adoption studies for a genetic contribution to adult psychiatric disorders. Int Rev Psychiatry 2004, 16:260-283.

16. Thapar A, Cooper M, Jefferies R, Stergiakouli E: What causes attention deficit hyperactivity disorder? Arch Dis Child 2012, 97:260-265

17. Szatmari $P$, Jones MB, Zwaigenbaum L, MacLean JE: Genetics of autism: overview and new directions. J Autism Dev Disord 1998, 28:351-368.

18. Wray NR, Gottesman II: Using summary data from the danish national registers to estimate heritabilities for schizophrenia, bipolar disorder, and major depressive disorder. Front Genet 2012, 3:118.

19. Gershon ES, Hamovit J, Guroff JJ, Dibble E, Leckman JF, Sceery W, Targum SD Nurnberger JI Jr, Goldin LR, Bunney WE Jr: A family study of schizoaffective, bipolar I, bipolar II, unipolar, and normal control probands. Arch Gen Psychiatry 1982, 39:1157-1167.

20. Maier W, Lichtermann D, Minges J, Hallmayer J, Heun R, Benkert O, Levinson DF: Continuity and discontinuity of affective disorders and schizophrenia. Results of a controlled family study. Arch Gen Psychiatry 1993, 50:871-883.

21. Gershon ES, DeLisi LE, Hamovit J, Nurnberger JI Jr, Maxwell ME, Schreiber J, Dauphinais D, Dingman CW 2nd, Guroff JJ: A controlled family study of chronic psychoses. Schizophrenia and schizoaffective disorder. Arch Gen Psychiatry 1988, 45:328-336. 
22. Kendler KS, McGuire M, Gruenberg AM, O'Hare A, Spellman M, Walsh D: The roscommon family study. IV. Affective illness, anxiety disorders, and alcoholism in relatives. Arch Gen Psychiatry 1993, 50:952-960.

23. Lichtenstein P, Yip BH, Bjork C, Pawitan Y, Cannon TD, Sullivan PF, Hultman $\mathrm{CM}$ : Common genetic determinants of schizophrenia and bipolar disorder in Swedish families: a population-based study. Lancet 2009, 373:234-239.

24. Cardno AG, Rijsdijk FV, Sham PC, Murray RM, McGuffin P: A twin study of genetic relationships between psychotic symptoms. Am J Psychiatry 2002, 159:539-545.

25. Van Snellenberg JX, de Candia T: Meta-analytic evidence for familial coaggregation of schizophrenia and bipolar disorder. Arch Gen Psychiatry 2009, 66:748-755.

26. Sullivan PF, Magnusson C, Reichenberg A, Boman M, Dalman C, Davidson M, Fruchter E, Hultman CM, Lundberg M, Långström N, Weiser M, Svensson AC, Lichtenstein P: Family history of schizophrenia and bipolar disorder as risk factors for autism. Arch Gen Psychiatry 2012, 69:1099-1103.

27. Larsson $H$, Rydén $E$, Boman $M$, Långström N, Lichtenstein $P$, Landén M: Risk of bipolar disorder and schizophrenia in relatives of people with attention-deficit hyperactivity disorder. Br J Psychiatry 2013, 203:103-106.

28. Rasic D, Hajek T, Alda M, Uher R: Risk of mental illness in offspring of parents with schizophrenia, bipolar disorder, and major depressive disorder: a meta-analysis of family high-risk studies. Schizophr Bull 2013, 40:28-38.

29. Vandeleur CL, Merikangas KR, Strippoli MP, Castelao E, Preisig M: Specificity of psychosis, mania and major depression in a contemporary family study. Mol Psychiatry 2014, 19:209-213.

30. David AS, Malmberg A, Brandt L, Allebeck P, Lewis G: IQ and risk for schizophrenia: a population-based cohort study. Psychol Med 1997 27:1311-1323.

31. de la Serna E, Baeza I, Toro J, Andres S, Puig O, Sanchez-Guistau V, Romero S, Bernardo M, Castro-Fornieles J: Relationship between clinical and neuropsychological characteristics in child and adolescent first degree relatives of subjects with schizophrenia. Schizophr Res 2010, 116:159-167.

32. Gur RE, Nimgaonkar VL, Almasy L, Calkins ME, Ragland JD, Pogue-Geile MF, Kanes S, Blangero J, Gur RC: Neurocognitive endophenotypes in a multiplex multigenerational family study of schizophrenia. Am J Psychiatry 2007, 164:813-819.

33. Toulopoulou T, Goldberg TE, Mesa IR, Picchioni M, Rijsdijk F, Stahl D, Cherny SS, Sham P, Faraone SV, Tsuang M, Weinberger DR, Seidman LJ, Murray RM: Impaired intellect and memory: a missing link between genetic risk and schizophrenia? Arch Gen Psychiatry 2010, 67:905-913.

34. Cross-Disorder Group of the Psychiatric Genomics Consortium: Identification of risk loci with shared effects on five major psychiatric disorders: a genome-wide analysis. Lancet 2013, 381:1371-1379.

35. Green EK, Grozeva D, Jones I, Jones L, Kirov G, Caesar S, Gordon-Smith K, Fraser C, Forty L, Russell E, Hamshere ML, Moskvina V, Nikolov I, Farmer A, McGuffin P, Wellcome Trust Case Control C, Holmans PA, Owen MJ, O'Donovan MC, Craddock N: The bipolar disorder risk allele at CACNA1C also confers risk of recurrent major depression and of schizophrenia. Mol Psychiatry 2010, 15:1016-1022.

36. Ferreira MA, O'Donovan MC, Meng YA, Jones IR, Ruderfer DM, Jones $L$, Fan J, Kirov G, Perlis RH, Green EK, Smoller JW, Grozeva D, Stone J, Nikolov I, Chambert K, Hamshere ML, Nimgaonkar VL, Moskvina V, Thase ME, Caesar S, Sachs GS, Franklin J, Gordon-Smith K, Ardlie KG, Gabriel SB, Fraser C, Blumenstiel B, Defelice M, Breen G, Gill M, et al: Collaborative genomewide association analysis supports a role for ANK3 and CACNA1C in bipolar disorder. Nat Genet 2008, 40:1056-1058.

37. The Schizophrenia Psychiatric Genome-Wide Association Study (GWAS) Consortium: Genome-wide association study identifies five new schizophrenia loci. Nat Genet 2011, 43:969-976.

38. Psychiatric GWAS Consortium Bipolar Disorder Working Group: Large-scale genome-wide association analysis of bipolar disorder identifies a new susceptibility locus near ODZ4. Nat Genet 2011, 43:977-983.

39. O'Donovan MC, Craddock N, Norton N, Williams H, Peirce T, Moskvina V, Nikolov I, Hamshere M, Carroll L, Georgieva L, Dwyer S, Holmans P, Marchini JL, Spencer CC, Howie B, Leung HT, Hartmann AM, Möller HJ, Morris DW, Shi Y, Feng G, Hoffmann P, Propping P, Vasilescu C, Maier W, Rietschel M, Zammit S, Schumacher J, Quinn EM, Schulze TG, et al: Identification of loci associated with schizophrenia by genome-wide association and followup. Nat Genet 2008, 40:1053-1055.
40. Williams HJ, Norton N, Dwyer S, Moskvina V, Nikolov I, Carroll L, Georgieva L, Williams NM, Morris DW, Quinn EM, Giegling I, Ikeda M, Wood J, Lencz T, Hultman C, Lichtenstein P, Thiselton D, Maher BS, Malhotra AK, Riley B, Kendler KS, Gill M, Sullivan P, Sklar P, Purcell S, Nimgaonkar VL, Kirov G, Molecular Genetics of Schizophrenia Collaboration (MGS) International Schizophrenia Consortium (ISC), SGENE-plus, GROUP, et al: Fine mapping of ZNF804A and genome-wide significant evidence for its involvement in schizophrenia and bipolar disorder. Mol Psychiatry 2011, 16:429-441.

41. Cichon S, Mühleisen TW, Degenhardt FA, Mattheisen M, Miró X, Strohmaie J, Steffens M, Meesters C, Herms S, Weingarten M, Priebe L, Haenisch B, Alexander M, Vollmer J, Breuer R, Schmäl C, Tessmann P, Moebus S, Wichmann HE, Schreiber S, Müller-Myhsok B, Lucae S, Jamain S, Leboyer M, Bellivier F, Etain B, Henry C, Kahn JP, Heath S, Bipolar Disorder Genome Study (BiGS) Consortium, et al: Genome-wide association study identifies genetic variation in neurocan as a susceptibility factor for bipolar disorder. Am J Hum Genet 2011, 88:372-381.

42. Mühleisen TW, Mattheisen M, Strohmaier J, Degenhardt F, Priebe L, Schultz CC, Breuer R, Meier S, Hoffmann P, Rivandeneira F, Hofman A, Uitterlinden AG, Moebus S, Gieger C, Emeny R, Ladwig KH, Wichmann HE, Schwarz M, Kammerer-Ciernioch J, Schlösser RG, Nenadic I, Sauer H, Mössner R, Maier W, Rujescu D, Lange C, Ophoff RA, Schulze TG, Rietschel M, GROUP Investigators: Association between schizophrenia and common variation in neurocan (NCAN), a genetic risk factor for bipolar disorder. Schizophr Res 2012, 138:69-73.

43. Purcell SM, Wray NR, Stone JL, Visscher PM, O'Donovan MC, Sullivan PF, Sklar P: Common polygenic variation contributes to risk of schizophrenia and bipolar disorder. Nature 2009, 460:748-752.

44. Ripke S, O'Dushlaine C, Chambert K, Moran JL, Kähler AK, Akterin S, Bergen SE, Collins AL, Crowley JJ, Fromer M, Kim Y, Lee SH, Magnusson PK, Sanchez N, Stahl EA, Williams S, Wray NR, Xia K, Bettella F, Borglum AD, Bulik-Sullivan BK, Cormican P, Craddock N, de Leeuw C, Durmishi N, Gill M, Golimbet V, Hamshere ML, Holmans P, Hougaard DM, et al: Genome-wide association analysis identifies 13 new risk loci for schizophrenia. Nat Genet 2013, 45:1150-1159.

45. Hamshere ML, Stergiakouli E, Langley K, Martin J, Holmans P, Kent L, Owen MJ, Gill M, Thapar A, O'Donovan M, Craddock N: Shared polygenic contribution between childhood attention-deficit hyperactivity disorder and adult schizophrenia. Br J Psychiatry 2013, 203:107-111.

46. Vorstman JA, Anney RJ, Derks EM, Gallagher L, Gill M, de Jonge MV, van Engeland H, Kahn RS, Ophoff RA, Autism Genome Project, the International Schizophrenia Consortium: No evidence that common genetic risk variation is shared between schizophrenia and autism. Am J Med Genet B Neuropsychiatr Genet 2013, 162B:55-60.

47. Lencz T, Knowles E, Davies G, Guha S, Liewald DC, Starr JM, Djurovic S, Melle I, Sundet K, Christoforou A, Reinvang I, Mukherjee S, DeRosse P, Lundervold A, Steen VM, John M, Espeseth T, Räikkönen K, Widen E, Palotie A, Eriksson JG, Giegling I, Konte B, Ikeda M, Roussos P, Giakoumaki S, Burdick KE, Payton A, Ollier W, Horan M, et al: Molecular genetic evidence for overlap between general cognitive ability and risk for schizophrenia: a report from the Cognitive Genomics consorTium (COGENT). Mol Psychiatry 2014, 19:168-174.

48. McIntosh AM, Gow A, Luciano M, Davies G, Liewald DC, Harris SE, Corley J, Hall J, Starr JM, Porteous DJ, Tenesa A, Visscher PM, Deary IJ: Polygenic risk for schizophrenia is associated with cognitive change between childhood and old age. Biol Psychiatry 2013, 73:938-943.

49. van Scheltinga AF T, Bakker SC, van Haren NE, Derks EM, BuizerVoskamp JE, Cahn W, Ripke S, Ophoff RA, Kahn RS: Schizophrenia genetic variants are not associated with intelligence. Psychol Med 2013, 43:2563-2570.

50. Yang J, Lee SH, Goddard ME, Visscher PM: GCTA: a tool for genome-wide complex trait analysis. Am J Hum Genet 2011, 88:76-82.

51. Cross-Disorder Group of the Psychiatric Genomics Consortium, Lee SH, Ripke S, Neale BM, Faraone SV, Purcell SM, Perlis RH, Mowry BJ, Thapar A, Goddard ME, Witte JS, Absher D, Agartz I, Akil H, Amin F, Andreassen OA, Anjorin A, Anney R, Anttila V, Arking DE, Asherson P, Azevedo MH, Backlund L, Badner JA, Bailey AJ, Banaschewski T, Barchas JD, Barnes MR, Barrett TB, Bass N, et al: Genetic relationship between five psychiatric disorders estimated from genome-wide SNPs. Nat Genet 2013, 45:984-994

52. Rommelse NN, Franke B, Geurts HM, Hartman CA, Buitelaar JK: Shared heritability of attention-deficit/hyperactivity disorder and autism spectrum disorder. Eur Child Adolesc Psychiatry 2010, 19:281-295. 
53. Nijmeijer JS, Arias-Vásquez A, Rommelse NN, Altink ME, Anney RJ, Asherson P, Banaschewski T, Buschgens CJ, Fliers EA, Gill M, Minderaa RB, Poustka L, Sergeant JA, Buitelaar JK, Franke B, Ebstein RP, Miranda A, Mulas F, Oades $\mathrm{RD}$, Roeyers $\mathrm{H}$, Rothenberger A, Sonuga-Barke EJ, Steinhausen HC, Faraone SV, Hartman CA, Hoekstra PJ: Identifying loci for the overlap between attention-deficit/hyperactivity disorder and autism spectrum disorder using a genome-wide QTL linkage approach. J Am Acad Child Adolesc Psychiatry 2010, 49:675-685.

54. Mulligan A, Anney RJ, O'Regan M, Chen W, Butler L, Fitzgerald M, Buitelaar J, Steinhausen HC, Rothenberger A, Minderaa R, Nijmeijer J, Hoekstra PJ, Oades RD, Roeyers H, Buschgens C, Christiansen H, Franke B, Gabriels I, Hartman C, Kuntsi J, Marco R, Meidad S, Mueller U, Psychogiou L, Rommelse N, Thompson M, Uebel H, Banaschewski T, Ebstein R, Eisenberg J, et al: Autism symptoms in Attention-Deficit/Hyperactivity Disorder: a familial trait which correlates with conduct, oppositional defiant, language and motor disorders. J Autism Dev Disord 2009, 39:197-209.

55. Faraone SV, Biederman J, Wozniak J: Examining the comorbidity between attention deficit hyperactivity disorder and bipolar I disorder: a metaanalysis of family genetic studies. Am J Psychiatry 2012, 169:1256-1266.

56. Lee SH, DeCandia TR, Ripke S, Yang J, Sullivan PF, Goddard ME, Keller MC, Visscher PM, Wray NR: Estimating the proportion of variation in susceptibility to schizophrenia captured by common SNPs. Nat Genet 2012, 44:247-250.

57. International Schizophrenia Consortium: Rare chromosomal deletions and duplications increase risk of schizophrenia. Nature 2008, 455:237-241.

58. Walsh T, McClellan JM, McCarthy SE, Addington AM, Pierce SB, Cooper GM Nord AS, Kusenda M, Malhotra D, Bhandari A, Stray SM, Rippey CF, Roccanova P, Makarov V, Lakshmi B, Findling RL, Sikich L, Stromberg T, Merriman B, Gogtay N, Butler P, Eckstrand K, Noory L, Gochman P, Long R, Chen Z, Davis S, Baker C, Eichler EE, et al: Rare structural variants disrupt multiple genes in neurodevelopmental pathways in schizophrenia. Science 2008, 320:539-543.

59. Xu B, Roos JL, Levy S, van Rensburg EJ, Gogos JA, Karayiorgou M: Strong association of de novo copy number mutations with sporadic schizophrenia. Nat Genet 2008, 40:880-885.

60. Williams NM, Franke B, Mick E, Anney RJ, Freitag CM, Gill M, Thapar A, O'Donovan MC, Owen MJ, Holmans P, Kent L, Middleton F, Zhang-James Y, Liu L, Meyer J, Nguyen TT, Romanos J, Romanos M, Seitz C, Renner TJ, Walitza S, Warnke A, Palmason H, Buitelaar J, Rommelse N, Vasquez AA, Hawi Z, Langley K, Sergeant J, Steinhausen HC, et al: Genome-wide analysis of copy number variants in attention deficit hyperactivity disorder: the role of rare variants and duplications at 15q13.3. Am J Psychiatry 2012, 169:195-204.

61. Williams NM, Zaharieva I, Martin A, Langley K, Mantripragada K, Fossdal R, Stefansson H, Stefansson K, Magnusson P, Gudmundsson OO, Gustafsson O, Holmans P, Owen MJ, O'Donovan M, Thapar A: Rare chromosomal deletions and duplications in attention-deficit hyperactivity disorder: a genome-wide analysis. Lancet 2010, 376:1401-1408.

62. Pinto D, Pagnamenta AT, Klei L, Anney R, Merico D, Regan R, Conroy J, Magalhaes TR, Correia C, Abrahams BS, Almeida J, Bacchelli E, Bader GD, Bailey A, Baird G, Battaglia A, Berney T, Bolshakova N, Bölte S, Bolton PF, Bourgeron T, Brennan S, Brian J, Bryson SE, Carson AR, Casallo G, Casey J, Chung BH, Cochrane $L$, Corsello $C$, et al: Functional impact of global rare copy number variation in autism spectrum disorders. Nature 2010, 466:368-372.

63. Cooper GM, Coe BP, Girirajan S, Rosenfeld JA, Vu TH, Baker C, Williams C, Stalker H, Hamid R, Hannig V, Abdel-Hamid H, Bader P, McCracken E, Niyazov D, Leppig K, Thiese H, Hummel M, Alexander N, Gorski J, Kussmann J, Shashi V, Johnson K, Rehder C, Ballif BC, Shaffer LG, Eichler EE: A copy number variation morbidity map of developmental delay. Nat Genet 2011, 43:838-846.

64. Grozeva D, Kirov G, Conrad DF, Barnes CP, Hurles M, Owen MJ, O'Donovan $M C$, Craddock N: Reduced burden of very large and rare CNVs in bipolar affective disorder. Bipolar Disord 2013, 15:893-898.

65. Grozeva D, Kirov G, Ivanov D, Jones IR, Jones L, Green EK, St Clair DM, Young AH, Ferrier N, Farmer AE, McGuffin P, Holmans PA, Owen MJ, O'Donovan MC, Craddock N, Wellcome Trust Case Control Consortium: Rare copy number variants: a point of rarity in genetic risk for bipolar disorder and schizophrenia. Arch Gen Psychiatry 2010, 67:318-327.

66. McQuillin A, Bass N, Anjorin A, Lawrence J, Kandaswamy R, Lydall G, Moran J, Sklar P, Purcell S, Gurling H: Analysis of genetic deletions and duplications in the University College London bipolar disorder case control sample. Eur J Hum Genet 2011, 19:588-592.
67. Malhotra D, McCarthy S, Michaelson JJ, Vacic V, Burdick KE, Yoon S, Cichon S, Corvin A, Gary S, Gershon ES, Gill M, Karayiorgou M, Kelsoe JR, Krastoshevsky O, Krause V, Leibenluft E, Levy DL, Makarov V, Bhandari A, Malhotra AK, McMahon FJ, Nöthen MM, Potash JB, Rietschel M, Schulze TG, Sebat J: High frequencies of de novo CNVs in bipolar disorder and schizophrenia. Neuron 2011, 72:951-963.

68. Zhang D, Cheng L, Qian Y, Alliey-Rodriguez N, Kelsoe JR, Greenwood T, Nievergelt C, Barrett TB, McKinney R, Schork N, Smith EN, Bloss C, Nurnberger J, Edenberg HJ, Foroud T, Sheftner W, Lawson WB, Nwulia EA, Hipolito M, Coryell W, Rice J, Byerley W, McMahon F, Schulze TG, Berrettini W, Potash JB, Belmonte PL, Zandi PP, McInnis MG, Zöllner S, et al: Singleton deletions throughout the genome increase risk of bipolar disorder. Mol Psychiatry 2009, 14:376-380.

69. Rucker JJ, Breen G, Pinto D, Pedroso I, Lewis CM, Cohen-Woods S, Uher R, Schosser A, Rivera M, Aitchison KJ, Craddock N, Owen MJ, Jones L, Jones I, Korszun A, Muglia P, Barnes MR, Preisig M, Mors O, Gill M, Maier W, Rice J, Rietschel M, Holsboer F, Farmer AE, Craig IW, Scherer SW, McGuffin P: Genome-wide association analysis of copy number variation in recurrent depressive disorder. Mol Psychiatry 2013, 18:183-189.

70. Stefansson H, Meyer-Lindenberg A, Steinberg S, Magnusdottir B, Morgen K, Arnarsdottir S, Bjornsdottir G, Walters GB, Jonsdottir G, Doyle OM, Tost H, Grimm O, Kristjansdottir S, Snorrason H, Davidsdottir SR, Gudmundsson LJ, Jonsson GF, Stefansdottir B, Helgadottir I, Haraldsson M, Jonsdottir B, Thygesen JH, Schwarz AJ, Didriksen M, Stensbøl TB, Brammer M, Kapur S, Halldorsson JG, Hreidarsson S, Saemundsen E, et al: CNVs conferring risk of autism or schizophrenia affect cognition in controls. Nature 2014, 505:361-366.

71. Brunetti-Pierri N, Jin R, He JP, Kessler RC, Lee S, Sampson NA, Viana MC, Andrade LH, Hu C, Karam EG, Ladea M, Medina-Mora ME, Ono Y, Posada-Villa J, Sagar R, Wells JE, Zarkov Z: Recurrent reciprocal 1q21.1 deletions and duplications associated with microcephaly or macrocephaly and developmental and behavioral abnormalities. Nat Genet 2008, 40:1466-1471.

72. Stefansson H, Rujescu D, Cichon S, Pietiläinen OP, Ingason A, Steinberg $S$, Fossdal R, Sigurdsson E, Sigmundsson T, Buizer-Voskamp JE, Hansen T, Jakobsen KD, Muglia P, Francks C, Matthews PM, Gylfason A, Halldorsson BV, Gudbjartsson D, Thorgeirsson TE, Sigurdsson A, Jonasdottir A, Jonasdottir A, Bjornsson A, Mattiasdottir S, Blondal T, Haraldsson M, Magnusdottir BB, Giegling I, Möller HJ, Hartmann A, et al: Large recurrent microdeletions associated with schizophrenia. Nature 2008, 455:232-236.

73. Kirov G, Rees E, Walters JT, Escott-Price V, Georgieva L, Richards AL, Chambert KD, Davies G, Legge SE, Moran JL, McCarroll SA, O'Donovan MC, Owen MJ: The penetrance of copy number variations for schizophrenia and developmental delay. Biol Psychiatry 2014, 75:378-385.

74. Rees E, Walters JT, Georgieva L, Isles AR, Chambert KD, Richards AL, Mahoney-Davies G, Legge SE, Moran JL, McCarroll SA, O'Donovan MC, Owen MJ, Kirov G: Analysis of copy number variations at 15 schizophrenia-associated loci. Br J Psychiatry 2014, 204:108-114.

75. Levinson DF, Duan J, Oh S, Wang K, Sanders AR, Shi J, Zhang N, Mowry BJ, Olincy A, Amin F, Cloninger CR, Silverman JM, Buccola NG, Byerley WF, Black DW, Kendler KS, Freedman R, Dudbridge F, Pe'er I, Hakonarson H, Bergen SE, Fanous AH, Holmans PA, Gejman PV: Copy number variants in schizophrenia: confirmation of five previous findings and new evidence for 3q29 microdeletions and VIPR2 duplications. Am J Psychiatry 2011, 168:302-316.

76. Kim HG, Kishikawa S, Higgins AW, Seong IS, Donovan DJ, Shen Y, Lally E, Weiss LA, Najm J, Kutsche K, Descartes M, Holt L, Braddock S, Troxell R, Kaplan L, Volkmar F, Klin A, Tsatsanis K, Harris DJ, Noens I, Pauls DL, Daly MJ, MacDonald ME, Morton CC, Quade BJ, Gusella JF: Disruption of neurexin 1 associated with autism spectrum disorder. Am J Hum Genet 2008, 82:199-207.

77. Dabell MP, Rosenfeld JA, Bader P, Escobar LF, El-Khechen D, Vallee SE, Dinulos MB, Curry C, Fisher J, Tervo R, Hannibal MC, Siefkas K, Wyatt PR, Hughes L, Smith R, Ellingwood S, Lacassie Y, Stroud T, Farrell SA, Sanchez-Lara PA, Randolph LM, Niyazov D, Stevens CA, Schoonveld C, Skidmore D, Mackay S, Miles JH, Moodley M, Huillet A, Neill NJ, et al: Investigation of NRXN1 deletions: clinical and molecular characterization. Am J Med Genet A 2013, 161A:717-731.

78. Bena F, Bruno DL, Eriksson M, van Ravenswaaij-Arts C, Stark Z, Dijkhuizen T, Gerkes E, Gimelli S, Ganesamoorthy D, Thuresson AC, Labalme A, Till M, Bilan F, Pasquier L, Kitzis A, Dubourgm C, Rossi M, Bottani A, Gagnebin M, Sanlaville D, Gilbert-Dussardier B, Guipponi M, van Haeringen A, Kriek M, Ruivenkamp C, 
Antonarakis SE, Anderlid BM, Slater HR, Schoumans J: Molecular and clinical characterization of 25 individuals with exonic deletions of NRXN1 and comprehensive review of the literature. Am J Med Genet B Neuropsychiatr Genet 2013, 162B:388-403.

79. Kirov G, Gumus D, Chen W, Norton N, Georgieva L, Sari M, O'Donovan MC, Erdogan F, Owen MJ, Ropers HH, Ullmann R: Comparative genome hybridization suggests a role for NRXN1 and APBA2 in schizophrenia. Hum Mol Genet 2008, 17:458-465.

80. Rujescu D, Ingason A, Cichon S, Pietiläinen OP, Barnes MR, Toulopoulou T, Picchioni M, Vassos E, Ettinger U, Bramon E, Murray $R$, Ruggeri $M$, Tosato $S$, Bonetto C, Steinberg S, Sigurdsson E, Sigmundsson T, Petursson H, Gylfason A, Olason PI, Hardarsson G, Jonsdottir GA, Gustafsson O, Fossdal R, Giegling I, Möller HJ, Hartmann AM, Hoffmann P, Crombie C, Fraser G, et al: Disruption of the neurexin 1 gene is associated with schizophrenia. Hum Mol Genet 2009, 18:988-996.

81. Kirov G, Grozeva D, Norton N, Ivanov D, Mantripragada KK, Holmans P, Craddock N, Owen MJ, O'Donovan MC: Support for the involvement of large copy number variants in the pathogenesis of schizophrenia. Hum Mol Genet 2009, 18:1497-1503.

82. Mulle JG, Dodd AF, McGrath JA, Wolyniec PS, Mitchell AA, Shetty AC, Sobreira NL, Valle D, Rudd MK, Satten G, Cutler DJ, Pulver AE, Warren ST: Microdeletions of 3q29 confer high risk for schizophrenia. Am J Hum Genet 2010, 87:229-236.

83. Kirov G, Pocklington AJ, Holmans P, Ivanov D, Ikeda M, Ruderfer D, Moran J, Chambert K, Toncheva D, Georgieva L, Grozeva D, Fjodorova M, Wollerton $R$, Rees E, Nikolov I, van de Lagemaat LN, Bayés A, Fernandez E, Olason PI, Böttcher Y, Komiyama NH, Collins MO, Choudhary J, Stefansson K, Stefansson H, Grant SG, Purcell S, Sklar P, O'Donovan MC, Owen MJ: De novo CNV analysis implicates specific abnormalities of postsynaptic signalling complexes in the pathogenesis of schizophrenia. Mol Psychiatry 2012, 17:142-153.

84. Mulle JG, Pulver AE, McGrath JA, Wolyniec PS, Dodd AF, Cutler DJ, Sebat J, Malhotra D, Nestadt G, Conrad DF, Hurles M, Barnes CP, Ikeda M, Iwata N, Levinson DF, Gejman PV, Sanders AR, Duan J, Mitchell AA, Peter I, Sklar P, O'Dushlaine CT, Grozeva D, O'Donovan MC, Owen MJ, Hultman CM, Kähler AK, Sullivan PF, Kirov G, Warren ST, Molecular Genetics of Schizophrenia Consortium: Reciprocal duplication of the Williams-Beuren syndrome deletion on chromosome $7 q 11.23$ is associated with schizophrenia. Biol Psychiatry 2014, 75:371-377.

85. Sanders SJ, Ercan-Sencicek AG, Hus V, Luo R, Murtha MT, Moreno-De-Luca D, Chu SH, Moreau MP, Gupta AR, Thomson SA, Mason CE, Bilguvar K, Celestino-Soper PB, Choi M, Crawford EL, Davis L, Wright NR, Dhodapkar RM, DiCola M, DiLullo NM, Fernandez TV, Fielding-Singh V, Fishman DO, Frahm S, Garagaloyan R, Goh GS, Kammela S, Klei L, Lowe JK, Lund SC, et al: Multiple recurrent de novo CNVs, including duplications of the $7 q 11.23$ Williams syndrome region, are strongly associated with autism. Neuron 2011, 70:863-885.

86. Velleman SL, Mervis CB: Children with 7q11.23 duplication syndrome: speech, language, cognitive, and behavioral characteristics and their implications for intervention. Perspect Lang Learn Educ 2011, 18:108-116.

87. Burnside RD, Pasion R, Mikhail FM, Carroll AJ, Robin NH, Youngs EL, Gadi IK, Keitges E, Jaswaney VL, Papenhausen PR, Potluri VR, Risheg H, Rush B, Smith J, Schwartz S, Tepperberg JH, Butler MG: Microdeletion/microduplication of proximal $15 q 11.2$ between BP1 and BP2: a susceptibility region for neurological dysfunction including developmental and language delay. Hum Genet 2011, 130:517-528.

88. Doornbos M, Sikkema-Raddatz B, Ruijvenkamp CA, Dijkhuizen T, Bijlsma EK, Gijsbers AC, Hilhorst-Hofstee Y, Hordijk R, Verbruggen KT, Kerstjens-Frederikse WS, van Essen T, Kok K, van Silfhout AT, Breuning M, van Ravenswaaij-Arts CM: Nine patients with a microdeletion $15 q 11.2$ between breakpoints 1 and 2 of the Prader-Willi critical region, possibly associated with behavioural disturbances. Eur J Med Genet 2009, 52:108-115.

89. von der Lippe C, Rustad C, Heimdal K, Rodningen OK: $15 q 11.2$ microdeletion - seven new patients with delayed development and/or behavioural problems. Eur J Med Genet 2011, 54:357-360.

90. Ingason A, Kirov G, Giegling I, Hansen T, Isles AR, Jakobsen KD, Kristinsson KT, le Roux L, Gustafsson O, Craddock N, Möller HJ, McQuillin A, Muglia P, Cichon S, Rietschel M, Ophoff RA, Djurovic S, Andreassen OA, Pietiläinen OP, Peltonen L, Dempster E, Collier DA, St Clair D, Rasmussen HB, Glenthøj BY, Kiemeney LA, Franke B, Tosato S, Bonetto C, Saemundsen E, et al: Maternally derived microduplications at 15q11-q13: implication of imprinted genes in psychotic illness. Am J Psychiatry 2011, 168:408-417.
91. Moreno-De-Luca D, Sanders SJ, Willsey AJ, Mulle JG, Lowe JK, Geschwind $\mathrm{DH}$, State MW, Martin CL, Ledbetter DH: Using large clinical data sets to infer pathogenicity for rare copy number variants in autism cohorts. $\mathrm{Mol}$ Psychiatry 2013, 18:1090-1095.

92. Dennis NR, Veltman MW, Thompson R, Craig E, Bolton PF, Thomas NS: Clinical findings in 33 subjects with large supernumerary marker(15) chromosomes and 3 subjects with triplication of 15q11-q13. Am J Med Genet A 2006, 140:434-441.

93. van Bon BW, Mefford HC, Menten B, Koolen DA, Sharp AJ, Nillesen WM, Innis JW, de Ravel TJ, Mercer CL, Fichera M, Stewart H, Connell LE, Ounap K, Lachlan K, Castle B, Van der Aa N, van Ravenswaaij C, Nobrega MA, SerraJuhé C, Simonic I, de Leeuw N, Pfundt R, Bongers EM, Baker C, Finnemore $P$, Huang S, Maloney VK, Crolla JA, van Kalmthout M, Elia M, Vandeweyer G, et al: Further delineation of the $15 q 13$ microdeletion and duplication syndromes: a clinical spectrum varying from non-pathogenic to a severe outcome. J Med Genet 2009, 46:511-523.

94. Ben-Shachar S, Lanpher B, German JR, Qasaymeh M, Potocki L, Nagamani SC, Franco LM, Malphrus A, Bottenfield GW, Spence JE, Amato S, Rousseau JA, Moghaddam B, Skinner C, Skinner SA, Bernes S, Armstrong N, Shinawi M, Stankiewicz P, Patel A, Cheung SW, Lupski JR, Beaudet AL, Sahoo T: Microdeletion 15q13.3: a locus with incomplete penetrance for autism, mental retardation, and psychiatric disorders. J Med Genet 2009, 46:382-388.

95. Pagnamenta AT, Wing K, Sadighi Akha E, Knight SJ, Bölte S, Schmötzer G, Duketis E, Poustka F, Klauck SM, Poustka A, Ragoussis J, Bailey AJ, Monaco AP, International Molecular Genetic Study of Autism Consortium: A 15q13.3 microdeletion segregating with autism. Eur J Hum Genet 2009, 17:687-692.

96. Miller DT, Shen Y, Weiss LA, Korn J, Anselm I, Bridgemohan C, Cox GF, Dickinson H, Gentile J, Harris DJ, Hegde V, Hundley R, Khwaja O, Kothare S, Luedke C, Nasir R, Poduri A, Prasad K, Raffalli P, Reinhard A, Smith SE, Sobeih MM, Soul JS, Stoler J, Takeoka M, Tan WH, Thakuria J, Wolff R, Yusupov R, Gusella JF, et al: Microdeletion/duplication at 15q13.2q13.3 among individuals with features of autism and other neuropsychiatric disorders. J Med Genet 2009, 46:242-248.

97. Guilmatre A, Dubourg C, Mosca AL, Legallic S, Goldenberg A, Drouin-Garraud V, Layet V, Rosier A, Briault S, Bonnet-Brilhault F, Laumonnier F, Odent S, Le Vacon G, Joly-Helas G, David V, Bendavid C, Pinoit JM, Henry C, Impallomeni C, Germano E, Tortorella G, Di Rosa G, Barthelemy C, Andres C, Faivre L, Frébourg T, Saugier Veber P, Campion D: Recurrent rearrangements in synaptic and neurodevelopmental genes and shared biologic pathways in schizophrenia, autism, and mental retardation. Arch Gen Psychiatry 2009, 66:947-956.

98. Levy D, Ronemus M, Yamrom B, Lee YH, Leotta A, Kendall J, Marks S, Lakshmi B, Pai D, Ye K, Buja A, Krieger A, Yoon S, Troge J, Rodgers L, lossifov I, Wigler M: Rare de novo and transmitted copy-number variation in autistic spectrum disorders. Neuron 2011, 70:886-897.

99. McCarthy SE, Makarov V, Kirov G, Addington AM, McClellan J, Yoon S, Perkins DO, Dickel DE, Kusenda M, Krastoshevsky O, Krause V, Kumar RA, Grozeva D, Malhotra D, Walsh T, Zackai EH, Kaplan P, Ganesh J, Krantz ID, Spinner NB, Roccanova P, Bhandari A, Pavon K, Lakshmi B, Leotta A, Kendall J, Lee YH, Vacic V, Gary S, lakoucheva LM, et al: Microduplications of 16p11.2 are associated with schizophrenia. Nat Genet 2009, 41:1223-1227.

100. Weiss LA, Shen Y, Korn JM, Arking DE, Miller DT, Fossdal R, Saemundsen E, Stefansson H, Ferreira MA, Green T, Platt OS, Ruderfer DM, Walsh CA, Altshuler D, Chakravarti A, Tanzi RE, Stefansson K, Santangelo SL, Gusella JF, Sklar P, Wu BL, Daly MJ, Autism Consortium: Association between microdeletion and microduplication at 16p11.2 and autism. N Engl J Med 2008, 358:667-675.

101. Shinawi M, Liu P, Kang SH, Shen J, Belmont JW, Scott DA, Probst FJ, Craigen WJ, Graham BH, Pursley A, Clark G, Lee J, Proud M, Stocco A, Rodriguez DL, Kozel BA, Sparagana S, Roeder ER, McGrew SG, Kurczynski TW, Allison L, Amato S, Savage S, Patel A, Stankiewicz P, Beaudet AL, Cheung SW, Lupski JR: Recurrent reciprocal 16p11.2 rearrangements associated with global developmental delay, behavioural problems, dysmorphism, epilepsy, and abnormal head size. J Med Genet 2010, 47:332-341.

102. Zufferey F, Sherr EH, Beckmann ND, Hanson E, Maillard AM, Hippolyte L, Macé A, Ferrari C, Kutalik Z, Andrieux J, Aylward E, Barker M, Bernier R, Bouquillon S, Conus P, Delobel B, Faucett WA, Goin-Kochel RP, Grant E, Harewood L, Hunter JV, Lebon S, Ledbetter DH, Martin CL, Männik K, Martinet D, Mukherjee P, Ramocki MB, Spence SJ, Steinman KJ, et al: A 600 $\mathrm{kb}$ deletion syndrome at $16 \mathrm{p} 11.2$ leads to energy imbalance and neuropsychiatric disorders. J Med Genet 2012, 49:660-668. 
103. Ingason A, Rujescu D, Cichon S, Sigurdsson E, Sigmundsson T, Pietiläinen OP, Buizer-Voskamp JE, Strengman E, Francks C, Muglia P, Gylfason A, Gustafsson O, Olason PI, Steinberg S, Hansen T, Jakobsen KD, Rasmussen HB, Giegling I, Möller HJ, Hartmann A, Crombie C, Fraser G, Walker N, Lonnqvist J, Suvisaari J, Tuulio-Henriksson A, Bramon E, Kiemeney LA, Franke $B$, Murray $R$, et al: Copy number variations of chromosome 16p13.1 region associated with schizophrenia. Mol Psychiatry 2011, 16:17-25.

104. Ikeda M, Aleksic B, Kirov G, Kinoshita Y, Yamanouchi Y, Kitajima T, Kawashima K, Okochi T, Kishi T, Zaharieva I, Owen MJ, O'Donovan MC, Ozaki $\mathrm{N}$, Iwata $\mathrm{N}$ : Copy number variation in schizophrenia in the Japanese population. Biol Psychiatry 2010, 67:283-286

105. Moreno-De-Luca D, SGENE Consortium, Mulle JG, Kaminsky EB, Sanders SJ, Simons Simplex Collection Genetics Consortium, Myers SM, Adam MP, Pakula AT, Eisenhauer NJ, Uhas K, Weik L, Guy L, Care ME, Morel CF, Boni C, Salbert BA, Chandrareddy A, Demmer LA, Chow EW, Surti U, Aradhya S, Pickering DL, Golden DM, Sanger WG, Aston E, Brothman AR, Gliem TJ, Thorland EC, GeneSTAR, et al: Deletion $17 q 12$ is a recurrent copy number variant that confers high risk of autism and schizophrenia. Am J Hum Genet 2010, 87:618-630.

106. Karayiorgou M, Morris MA, Morrow B, Shprintzen RJ, Goldberg R, Borrow J, Gos A, Nestadt G, Wolyniec PS, Lasseter VK, Eisen H, Childs B, Kazazian HH, Kucherlapati R, Antonarakis SE, Pulver AE, Housman DE: Schizophrenia susceptibility associated with interstitial deletions of chromosome 22q11. Proc Natl Acad Sci U S A 1995, 92:7612-7616.

107. Niarchou M, Zammit S, van Goozen SH, Thapar A, Tierling HM, Owen MJ, van den Bree MB: Psychopathology and cognition in children with 22q11.2 deletion syndrome. Br J Psychiatry 2014, 204:46-54.

108. Antshel KM, Aneja A, Strunge L, Peebles J, Fremont WP, Stallone K Abdulsabur N, Higgins AM, Shprintzen RJ, Kates WR: Autistic spectrum disorders in velo-cardio facial syndrome (22q11.2 deletion). J Autism Dev Disord 2007, 37:1776-1786.

109. Antshel KM, Fremont W, Roizen NJ, Shprintzen R, Higgins AM, Dhamoon A, Kates WR: ADHD, major depressive disorder, and simple phobias are prevalent psychiatric conditions in youth with velocardiofacial syndrome. J Am Acad Child Adolesc Psychiatry 2006, 45:596-603.

110. Rees E, Kirov G, Sanders A, Walters JT, Chambert KD, Shi J, Szatkiewicz J, O'Dushlaine C, Richards AL, Green EK, Jones I, Davies G, Legge SE, Moran JL, Pato C, Pato M, Genovese G, Levinson D, Duan J, Moy W, Göring HH, Morris D, Cormican P, Kendler KS, O'Neill FA, Riley B, Gill M, Corvin A, Craddock N, Wellcome Trust Case Control Consortium, et al: Evidence that duplications of 22q11.2 protect against schizophrenia. Mol Psychiatry 2014, 19:37-40.

111. O'Roak BJ, Deriziotis P, Lee C, Vives L, Schwartz JJ, Girirajan S, Karakoc E, Mackenzie AP, Ng SB, Baker C, Rieder MJ, Nickerson DA, Bernier R, Fisher SE, Shendure J, Eichler EE: Exome sequencing in sporadic autism spectrum disorders identifies severe de novo mutations. Nat Genet 2011, 43:585-589.

112. Neale BM, Kou Y, Liu L, Ma'ayan A, Samocha KE, Sabo A, Lin CF, Stevens C, Wang LS, Makarov V, Polak P, Yoon S, Maguire J, Crawford EL, Campbell NG, Geller ET, Valladares O, Schafer C, Liu H, Zhao T, Cai G, Lihm J, Dannenfelser R, Jabado O, Peralta Z, Nagaswamy U, Muzny D, Reid JG, Newsham I, Wu Y, et al: Patterns and rates of exonic de novo mutations in autism spectrum disorders. Nature 2012, 485:242-245.

113. Sanders SJ, Murtha MT, Gupta AR, Murdoch JD, Raubeson MJ, Willsey AJ, Ercan-Sencicek AG, DiLullo NM, Parikshak NN, Stein JL, Walker MF, Ober GT, Teran NA, Song Y, El-Fishawy P, Murtha RC, Choi M, Overton JD, Bjornson RD, Carriero NJ, Meyer KA, Bilguvar K, Mane SM, Sestan N, Lifton RP, Günel M, Roeder K, Geschwind DH, Devlin B, State MW: De novo mutations revealed by whole-exome sequencing are strongly associated with autism. Nature 2012, 485:237-241.

114. Iossifov I, Ronemus M, Levy D, Wang Z, Hakker I, Rosenbaum J, Yamrom B, Lee YH, Narzisi G, Leotta A, Kendall J, Grabowska E, Ma B, Marks S, Rodgers L, Stepansky A, Troge J, Andrews P, Bekritsky M, Pradhan K, Ghiban E, Kramer M, Parla J, Demeter R, Fulton LL, Fulton RS, Magrini VJ, Ye K, Darnell JC, Darnell RB, et al: De novo gene disruptions in children on the autistic spectrum. Neuron 2012, 74:285-299.

115. Rauch A, Wieczorek D, Graf E, Wieland T, Endele S, Schwarzmayr T, Albrecht B, Bartholdi D, Beygo J, Di Donato N, Dufke A, Cremer K, Hempel M, Horn D, Hoyer J, Joset P, Röpke A, Moog U, Riess A, Thiel CT, Tzschach A, Wiesener A, Wohlleber E, Zweier C, Ekici AB, Zink AM, Rump A, Meisinger C, Grallert H, Sticht $H$, et al: Range of genetic mutations associated with severe non-syndromic sporadic intellectual disability: an exome sequencing study. Lancet 2012, 380:1674-1682.
116. de Ligt J, Willemsen MH, van Bon BW, Kleefstra T, Yntema HG, Kroes T, Vulto-van Silfhout AT, Koolen DA, de Vries P, Gilissen C, del Rosario M, Hoischen A, Scheffer H, de Vries BB, Brunner HG, Veltman JA, Vissers LE: Diagnostic exome sequencing in persons with severe intellectual disability. N Engl J Med 2012, 367:1921-1929.

117. Saha S, Barnett AG, Foldi C, Burne TH, Eyles DW, Buka SL, McGrath JJ: Advanced paternal age is associated with impaired neurocognitive outcomes during infancy and childhood. PLoS Med 2009, 6:e40.

118. Reichenberg A, Gross R, Weiser M, Bresnahan M, Silverman J, Harlap S, Rabinowitz J, Shulman C, Malaspina D, Lubin G, Knobler HY, Davidson M, Susser E: Advancing paternal age and autism. Arch Gen Psychiatry 2006, 63:1026-1032.

119. Croen LA, Najjar DV, Fireman B, Grether JK: Maternal and paternal age and risk of autism spectrum disorders. Arch Pediatr Adolesc Med 2007, 161:334-340.

120. Durkin MS, Maenner MJ, Newschaffer CJ, Lee LC, Cunniff CM, Daniels JL, Kirby RS, Leavitt L, Miller L, Zahorodny W, Schieve LA: Advanced parental age and the risk of autism spectrum disorder. Am J Epidemiol 2008, 168:1268-1276.

121. Girard SL, Gauthier J, Noreau A, Xiong L, Zhou S, Jouan L, Dionne-Laporte A, Spiegelman D, Henrion E, Diallo O, Thibodeau P, Bachand I, Bao JY, Tong $\mathrm{AH}$, Lin $\mathrm{CH}$, Millet B, Jaafari N, Joober R, Dion PA, Lok S, Krebs MO, Rouleau $G A$ : Increased exonic de novo mutation rate in individuals with schizophrenia. Nat Genet 2011, 43:860-863.

122. Xu B, Roos JL, Dexheimer P, Boone B, Plummer B, Levy S, Gogos JA, Karayiorgou M: Exome sequencing supports a de novo mutational paradigm for schizophrenia. Nat Genet 2011, 43:864-868.

123. Fromer M, Pocklington AJ, Kavanagh DH, Williams HJ, Dwyer S, Gormley P, Georgieva L, Rees E, Palta P, Ruderfer DM, Carrera N, Humphreys I, Johnson JS, Roussos P, Barker DD, Banks E, Milanova V, Grant SG, Hannon E, Rose SA, Chambert K, Mahajan M, Scolnick EM, Moran JL, Kirov G, Palotie A, McCarroll SA, Holmans P, Sklar P, Owen MJ, et al: De novo mutations in schizophrenia implicate synaptic networks. Nature 2014, 506:179-184.

124. Purcell SM, Moran JL, Fromer M, Ruderfer D, Solovieff N, Roussos P, O'Dushlaine C, Chambert K, Bergen SE, Kähler A, Duncan L, Stahl E, Genovese G, Fernández E, Collins MO, Komiyama NH, Choudhary JS, Magnusson PK, Banks E, Shakir K, Garimella K, Fennell T, DePristo M, Grant SG, Haggarty SJ, Gabriel S, Scolnick EM, Lander ES, Hultman CM, Sullivan PF: A polygenic burden of rare disruptive mutations in schizophrenia. Nature 2014, 506:185-190

125. Tam GW, Redon R, Carter NP, Grant SG: The role of DNA copy number variation in schizophrenia. Biol Psychiatry 2009, 66:1005-1012.

126. Niere F, Wilkerson JR, Huber KM: Evidence for a fragile $X$ mental retardation protein-mediated translational switch in metabotropic glutamate receptor-triggered Arc translation and long-term depression. J Neurosci 2012, 32:5924-5936.

127. Kirov G, Rujescu D, Ingason A, Collier DA, O'Donovan MC, Owen MJ: Neurexin 1 (NRXN1) deletions in schizophrenia. Schizophr Bull 2009, 35:851-854.

128. Grant SG, Marshall MC, Page KL, Cumiskey MA, Armstrong JD: Synapse proteomics of multiprotein complexes: en route from genes to nervous system diseases. Hum Mol Genet 2005, 14:R225-R234.

129. Howes OD, Murray RM: Schizophrenia: an integrated sociodevelopmentalcognitive model. Lancet 2013. 10.1016/S0140-6736(13)62036-X.

130. Craddock N, Owen MJ: The Kraepelinian dichotomy - going, going... but still not gone. Br J Psychiatry 2010, 196:92-95.

131. Owen MJ: Intellectual disability and major psychiatric disorders: a continuum of neurodevelopmental causality. Br J Psychiatry 2012, 200:268-269.

132. Cuthbert BN, Insel TR: Toward new approaches to psychotic disorders: the NIMH Research Domain Criteria project. Schizophr Bull 2010, 36:1061-1062.

133. Doherty JL, Owen MJ: The Research Domain Criteria: moving the goalposts to change the game. Br J Psychiatry 2014, 204:171-173.

134. Uher R: Genomics and the classification of mental illness: focus on broader categories. Genome Med 2013, 5:97.

135. Manning M, Hudgins L: Array-based technology and recommendations for utilization in medical genetics practice for detection of chromosomal abnormalities. Genet Med 2010, 12:742-745.

136. Sherr EH, Michelson DJ, Shevell MI, Moeschler JB, Gropman AL, Ashwal S: Neurodevelopmental disorders and genetic testing: Current approaches and future advances. Ann Neurol 2013. 10.1002/ana.23950.

137. Gershon ES, Alliey-Rodriguez N: New ethical issues for genetic counseling in common mental disorders. Am J Psychiatry 2013, 170:968-976. 
138. van den Bree MB, Miller G, Mansell E, Thapar A, Flinter F, Owen MJ: The internet is parents' main source of information about psychiatric manifestations of 22q11.2 deletion syndrome (22q11.2DS). Eur J Med Genet 2013, 56:439-441.

139. Martin N, Mikhaelian M, Cytrynbaum C, Shuman C, Chitayat DA, Weksberg R, Bassett AS: 22q11.2 deletion syndrome: attitudes towards disclosing the risk of psychiatric illness. J Genet Couns 2012, 21:825-834.

140. Barbaresi WJ, Colligan RC, Weaver AL, Voigt RG, Killian JM, Katusic SK: Mortality, ADHD, and psychosocial adversity in adults with childhood ADHD: a prospective study. Pediatrics 2013, 131:637-644.

141. Seltzer MM, Krauss MW, Shattuck PT, Orsmond G, Swe A, Lord C: The symptoms of autism spectrum disorders in adolescence and adulthood. J Autism Dev Disord 2003, 33:565-581.

142. Niemi LT, Suvisaari JM, Tuulio-Henriksson A, Lonnqvist JK: Childhood developmental abnormalities in schizophrenia: evidence from high-risk studies. Schizophr Res 2003, 60:239-258.

143. Henin A, Biederman J, Mick E, Hirshfeld-Becker DR, Sachs GS, Wu Y, Yan L, Ogutha J, Nierenberg AA: Childhood antecedent disorders to bipolar disorder in adults: a controlled study. J Affect Disord 2007, 99:51-57.

144. Caspi A, Reichenberg A, Weiser M, Rabinowitz J, Kaplan Z, Knobler H, Davidson-Sagi N, Davidson M: Cognitive performance in schizophrenia patients assessed before and following the first psychotic episode. Schizophr Res 2003, 65:87-94.

145. Kremen WS, Vinogradov S, Poole JH, Schaefer CA, Deicken RF, Factor-Litvak P, Brown AS: Cognitive decline in schizophrenia from childhood to midlife: a 33-year longitudinal birth cohort study. Schizophr Res 2010, 118:1-5.

146. Seidman LJ, Biederman J, Monuteaux MC, Doyle AE, Faraone SV: Learning disabilities and executive dysfunction in boys with attention-deficit/ hyperactivity disorder. Neuropsychology 2001, 15:544-556.

147. Clark L, Iversen SD, Goodwin GM: Sustained attention deficit in bipolar disorder. Br J Psychiatry 2002, 180:313-319.

148. Fibiger HC: Psychiatry, the pharmaceutical industry, and the road to better therapeutics. Schizophr Bull 2012, 38:649-650.

149. Ruderfer DM, Fanous AH, Ripke S, McQuillin A, Amdur RL, Schizophrenia Working Group of the Psychiatric Genomics Consortium; Bipolar Disorder Working Group of the Psychiatric Genomics Consortium; Cross-Disorder Working Group of the Psychiatric Genomics Consortium, Gejman PV, O'Donovan MC, Andreassen OA, Djurovic S, Hultman CM, Kelsoe JR, Jamain S, Landén M, Leboyer M, Nimgaonkar V, Nurnberger J, Smoller JW, Craddock N, Corvin A, Sullivan PF, Holmans P, Sklar P, Kendler KS: Polygenic dissection of diagnosis and clinical dimensions of bipolar disorder and schizophrenia. Mol Psychiatry 2013. doi: 10.1038/mp.2013.138.

150. Craddock N, Jones L, Jones IR, Kirov G, Green EK, Grozeva D, Moskvina V Nikolov I, Hamshere ML, Vukcevic D, Caesar S, Gordon-Smith K, Fraser C, Russell E, Norton N, Breen G, St Clair D, Collier DA, Young AH, Ferrier IN, Farmer A, McGuffin P, Holmans PA, Donnelly P, Owen MJ, O'Donovan MC, Wellcome Trust Case Control Consortium (WTCCC): Strong genetic evidence for a selective influence of GABAA receptors on a component of the bipolar disorder phenotype. Mol Psychiatry 2010, 15:146-153.

doi:10.1186/gm546

Cite this article as: Doherty and Owen: Genomic insights into the overlap between psychiatric disorders: implications for research and clinical practice. Genome Medicine 2014 6:29. 